\title{
Chronology of Japanese Historical Events, 1905-1957
}

The following chronology records major historical events that led to and occurred during the time ofJapan's war in China and the Pacific, followed by the American Occupation after the war. Integrated in the timeline are important local and regional events that impacted the people of Oita Prefecture during this period. Ofspecial note is the activity of the Oita $47^{\text {th }}$ Regiment, the locally recruited army unit representing the people of Oita Prefecture throughout the waryears. The years shown in parenthesis indicate the traditional Japanese calendar as calculated from the beginning of each emperor's reign until his death.

Date Events

1905 (明治 38 年)

August 9-September 5: Treaty of Portsmouth negotiated and signed in U.S. state of New Hampshire with President Theodore Roosevelt as mediator, acknowledging Japan's defeat of Russia in the Russo-Japanese War and granting Japan authority over parts of northeast China and Korea.Japan is emboldened as a new world power.

1926 (昭和元年)

December 26: Hirohito assumes throne as emperor following the death of his father.

1928 (昭和 3 年)

November 15: Hirohito declared a deity, instituting the cult of emperor worship.

1931 (昭和6年)

September 18: Manchurian Incident (also known as Mukden Incident) leads to Japanese military and civil control over northeast China.

1932 (昭和 7 年)

December 15: Oita $47^{\text {th }}$ Regiment ships out to China.

December 21: Oita $47^{\text {th }}$ Regiment arrives in Zunhua, China, via Pusan, Shenyang (Mukden), and Changchun (Hsinking). 
1933 (昭和 8 年)

October 2: Oita $47^{\text {th }}$ Regiment completes China deployment and returns to Oita.

1934 (昭和 9 年)

February 15: Naval base established in Saiki City, southern coastal city in

Oita Prefecture.

1936

November 25, Anti-Comintern Pact signed between Nazi Germany and Japan. Italy joined the Pact in November, 1937

1937 (昭和 12 年)

July 7: Marco Polo Bridge Incident; Japanese and Chinese troops engage in battle outside Beijing. In response, Japan sends more troops to China and full-scale war ensues.

July 27: Oita $47^{\text {th }}$ Regiment ships out to China, arriving in Zhujiawu, via Pusan, Shenyang, and Beijing.

December 10: Oita $47^{\text {th }}$ Regiment on front lines in Battle of Nanjing.

1938 (昭和 13 年)

March 24: Oita $47^{\text {th }}$ Regiment arrives in Wuhu, home of coauthor Ran Ying Porter's family, as occupying force.

1939 (昭和 14 年)

October 1: Naval air base opens in Usa, a northern coastal city in Oita Prefecture.

1940 (昭和 15 年)

September 27: Tripartite Pact signed in Berlin between Germany, Italy, and Japan.

1941 (昭和 16 年)

August: Admiral Isoroku Yamamoto establishes training center for attack on Pearl Harbor in Saiki Bay, in Oita Prefecture.

September 5: Oita $47^{\text {th }}$ Regiment arrives in Gaoxiong, Taiwan, via Fuzhou, China.

October 17: General Hideki Tojo, minister of the army and a strong advocate for war, takes over as prime minister and forms new cabinet to advise the emperor. 
November 1: Admiral Yamamoto moves air attack training for Pearl Harbor attack from the southern city of Kagoshima to Saiki Bay.

November 19: Japanese fleet sails out of Saiki Bay, heading to the northern Japanese islands in the Kuriles, where attack forces rendezvous and proceed to Pearl Harbor.

December 7: Japanese Imperial Navy attacks Pearl Harbor (December 8 in Japan).

December 9: The emperor's Imperial Rescript, a defense of Japan's attack of Pearl Harbor and other locations in Asia, appears in newspapers across the country.

December 10: Japanese Navy sinks British battleships Prince of Wales and Repulse off coast of Malaysia.

December 25: Hong Kong surrenders to Japanese forces.

1942 (昭和 17 年)

January 2: Oita $47^{\text {th }}$ Regiment deployed to Philippines.

February 15: Singapore falls to Japan; celebrations held all over Japan.

March 8: Oita $47^{\text {th }}$ Regiment arrives in Surabaya on island of Java.

April 18: First air attacks on Tokyo, Yokohama, and Nagoya, known as the

Doolittle Raid, shock government and people of Japan.

June 5-7: Battle of Midway inflicts major defeat on Japanese Navy.

September 5: Oita $47^{\text {th }}$ Regiment arrives on island of Timor.

1943 (昭和 18 年)

April 18: Admiral Isoroku Yamamoto killed when his plane is shot down over the Pacific.

1944 (昭和 19 年)

June 15-July 9: Battle of Saipan in Mariana Islands, bringing major defeat of Japanese Army. U.S. forces now have a land base from which to attack Japan with B-29 bombers.

1945 (昭和 20 年)

January 1: American B-29s observed flying over Oita Prefecture for the first time as they head north for bombing targets in Honshu.

March 18: Americans attack targets on Kyushu with Grumman F6F Hellcat fighter planes and Curtiss SB2C Helldiver bombers, targeting several Oita locations for the first time and leading to many civilian casualties.

April 1: Battle of Okinawa begins. 
April 6-May 4: Kamikaze airmen from naval air base in Usa, Oita Prefecture, launch multiple missions against American ships around Okinawa.

April 21: American B-2gs and Grumman Hellcats bomb and strafe numerous locations in Oita Prefecture, leading to many civilian deaths.

May 5: American B-29 brought down over village of Takeda in Oita Prefecture. Surviving crewmen are taken to Tokyo and Fukuoka, where all but one are tortured and executed.

June 23: Battle of Okinawa ends.

August 2: Admiral Matome Ugaki, recently charged by Tokyo to prepare

Kyushu for expected imminent invasion, moves his headquarters from Kagoshima on the southern tip of Kyushu to the naval base in Oita City. August 6: Atomic bomb dropped on Hiroshima.

August 9: Atomic bomb dropped on Nagasaki.

August 11: American military ceases bombing of Oita Prefecture.

August 15: Emperor declares Japan will cease fighting and agree to Allied terms.

August 30: Oita $47^{\text {th }}$ Regiment burns its battle flag as it surrenders to Australian forces in Indonesia.

September 2: Japanese representatives Mamoru Shigemitsu, representing the Foreign Ministry, and General Yoshijiro Umezu, representing the military, sign the Instrument of Surrender aboard the USS Missouri in Tokyo Bay. Both men are from Oita Prefecture.

October 13: Advance team of seventeen American Occupation soldiers arrives in Oita Prefecture from the recently landed $28^{\text {th }}$ Marine Regiment.

1946 (昭和 21 年)

December 15: American Occupation forces establish permanent regional headquarters in resort city of Beppu, Oita Prefecture.

1952 (昭和 27 年)

April 28: American Occupation ends, while American forces remain in Beppu during Korean War.

1957 (昭和 32 年)

March 25: American forces close military base in Beppu. 